\title{
EDITING OF MATHEMATICAL TEXTS ON LMS WEB PAGES
}

\section{Andrea KUBIŠOVÁ}

\begin{abstract}
The article offers the authors of mathematical texts two ways how to write mathematical texts rich in mathematical formulas on the web pages. Both of the introduced ways give quality outputs for the first sight and every user without any deeper ICT skills is able to understand the algorithm and easily place mathematical formulas on the internet. In the conclusion is made a comparison of both, while the main emphasis is laid on the possibility to edit the formulas on the web quickly in future.
\end{abstract}

Key words: LMS, text and HTML format, mathematical texts, formula, export, MS Equations 3.0, TeX, mathematical mode, WinEdt.

\section{PSANÍ MATEMATICKÉHO TEXTU NA LMS WEBOVÝCH STRÁNKÁCH}

Resumé: Př́spěvek nabízí tvi̊rcům matematických textů dvě možnosti, jak na webových stránkách zapisovat text bohatý na matematické vzorce. Obě uvedené možnosti dávaji na prvni pohled kvalitni výstupy a je v možnostech každého uživatele bez hlubšich ICT dovedností algoritmu jejich zápisu porozumèt a tak matematické vzorce jednoduše umistit v rámci LMS aplikací na internet. V závéru je provedeno srovnáni obou postupi̊, kdy byl jednoznačně kladen di̊raz na možnost rychlé následné editace na webu zobrazených vzorců.

Klićcová slova: LMS, textový a HTML formát, matematický text, vzorec, export, MS Equations 3.0, TeX, matematický režim, WinEdt.

\section{1 Úvod}

Rozvoj a popularizace informačních a komunikačních technologií (Information and Communication Technologies - ICT) má za následek též významný vliv na rozvoj počítačově podporované výuky (Computer Assisted Learning - CAL), obzvláště populární je $\mathrm{v}$ dnešní době rychle se rozvíjející oblast elearningu.

Učitel, který chce využít náklonnosti studentů k moderním ICT technologiím jako je vlastní PC a připojení na internet, jim potřebuje $v$ první řadě zprostředkovat studijní materiály $\mathrm{v}$ podobě výkladových textů, doplněné též o interaktivní testy, obrázky, animace, audio či video materiály, stejně jako o prostředky elektronické komunikace (diskusní fóra, on-line konzultace). Vše zastř̌šuje pevná a srozumitelná struktura a tutorské pokyny jak při studiu postupovat.

Dnes již existuje široká škála moderních vzdělávacích systémů pro řízení výuky (Learning Management Systems - LMS), na př́klad uved'me na vysokých školách hojně využívaný open source systém Moodle. Stávají se studentovým přirozeným virtuálním studijním prostředím a učitelům technicky značně usnadňují umístění uvedených prvků elearnigových kurzů na internet. S příchodem
LMS apikací se stalo publikování na internetu př́istupnější velkému množství autorů, kteří nevládnou dovedností vytvořit samostatně svůj web. Př́́mé psaní jeho stránek v HTML kódu je zde nahrazeno jejich psaním $\mathrm{v}$ textovém formátu prímo tak, jak budou zobrazeny, a tento kód je v pozadí generován automaticky. Velmi zjednodušeně řečeno se učitel podílí pouze na naplnění databáze připravenými webovými stránkami $\mathrm{s}$ vlastním textem, přičemž má možnost určovat strukturu (pořadí průchodu) těchto stránek. Dále též do připravených adresářů jednoduše ukládá další soubory ostatních typů.

$\mathrm{V}$ př́rodních vědách, jako je napřr. matematika či fyzika, si ovšem autor nevystačí pouze se zápisem prostého textu, velmi často je třeba zapsat matematický vzorec. Jak bývá obvyklé, tvůrci obecně využívaných aplikací na tuto záležitost př́lišs nemyslí. Následující kapitoly nepřinášejí úplný přehled všech možností, jakým způsobem zobrazit matematické vzorce na webových stránkách, ale nabízí i čtenářům bezhlubších ICT dovedností dva z možných postupů. Jejich využití a porovnání bude demonstrováno na zápisu vzorce pro výpočet RPSN tak, jak se uvádí $\mathrm{v}$ př́loze zákona č. 321/2001 Sb., na webovou stránku jakožto objekt typu přednáška v programu Moodle, který 
je oficiálním LMS autorčiny domovské vzdělávací instituce.

\section{MS Equations a WinEdt}

\section{MS Equations}

První z popsaných cest je známá uživatelům programů firmy Microsoft. Mezi tvůrci webů je hojně rozšiřená především proto, že program MS Word je nejčastěji užívaným textovým editorem.

Vzorec se zde nejprve vytvoř́ jako objekt doplňkového programu MS Equations 3.0 (Editor rovnic 3.0). Sestavení vzorců je založené na intuitivním "stavebnicovém" principu skládání matematických symbolů (viz Obr 1). Poté by bylo vhodné jej exportovat do podoby obrázku, který je pak nutné umístit na internet.

Nabízelo by se, aby byl pod volbou Objekt Rovnice - Přvést - Typ objektu k dispozici nabízen nějaký obrázkový formát, čemuž tak ovšem není. Uživateli tedy nezbývá než spokojit se s „kutilskou“ cestou přes stisk klávesy PrintScreen a vložením získaného aktuálního stavu monitoru do dalšího MS programu Malování, kde je již možné vhodně (ovšem od ruky) vybraný obdélníkový výřez uložit jako nový obrázek ve zvoleném formátu, např̀.jpg, gif.

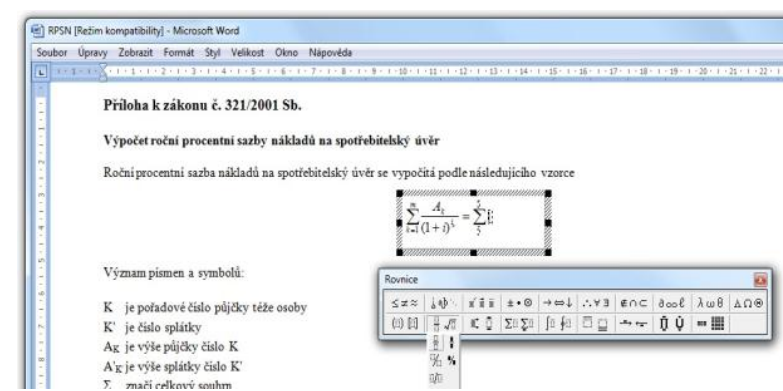

Obr 1: Editace objektu MS Equations 3.0.

Takto získaný soubor již stačí uložit do vhodného adresáŕe na př́slušném serveru (levé menu hlavní stránky kurzu Správa Soubory - Vložit soubor) a do požadované

stránky vložit pomocí tlačítka

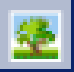

(Vložit/upravit obrázek) do upravované webové $\mathrm{v}$ textovém formátu, což je podrobně popsáno $\mathrm{v}$ uživatelské príručce $\mathrm{k}$ programu LMS Moodle.

Této akci odpovídá paralelní automatické vytvoření zápisu v HTML formátu pomocí tagu (značky) <img $s r c=\ldots>$ značkovacího jazyka HTML, které se při psaní webových stránek obecně používá při vkládání obrázku na jakoukoli webovou stránku. Znalost syntaxe značkovacího jazyka HTML je pro psaní v tomto formátu nutností. I zde je nejprve nutné umístit zdrojový obrázek, na nějž nás tento př́íkaz odkazuje, do vhodného adresáře na odpovídajícím serveru.

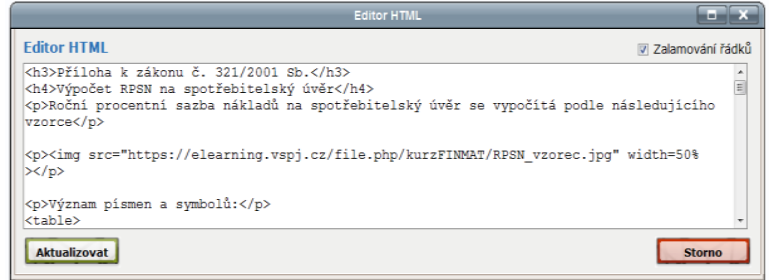

Obr 2: Odkaz na obrázek v HTML editoru.

Mezi oběma formáty zápisu textu tvořené webové stránky je možné (ale není nutné) se průběžně prepínat.

\section{WinEdt}

Podmínkou k použití druhé z nabízených možností je seznámení se se základní syntaxí užívanou ve značkovacím jazyce TeX, který se hojně používá pro počítačovou sazbu textů v matematických akademických kruzích. Pro naše účely se zabývejme pouze príkazy používanými v matematickém režimu programu TeX, tedy pouze sázením matematických vzorců. Popišme zde ovšem cestu schůdnou i pro člověka bez znalosti zákonitostí sémantiky a syntaxe tohoto jazyka.

$\mathrm{Na}$ internetu je k dispozici shareware s názvem WinEdt, nenápadný program, kterým lze nutnost této znalosti velmi jednoduše obejít. Samozřejmě že matematické myšlení a znalost principů jiného značkovacího jazyka HTML je pro $\mathrm{v}$ tomto prípadě výhodou. Nahrazením přsesného zápisu příkazů do prŕíkazového řádku pouhým klikáním pro výběr jejich ekvivalentů v připravených sadách tlačítek (Matematické, Řecké, Symboly, Mezinárodní, Typy písma, Funkce, Závorky, Značky operací, ...) se stal zápis vzorce $\mathrm{v}$ jazyce TeX lehce zdolatelným.

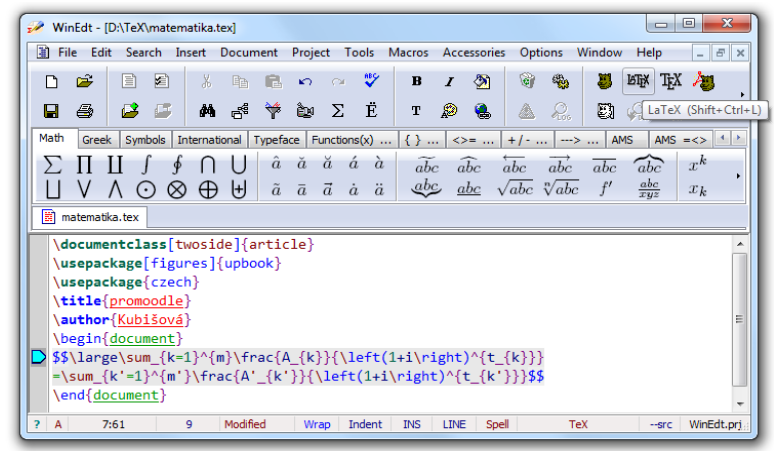

Obr 3: Získání syntaxe v programu WinEdt.

Vznikající zápis je sice graficky méně názorný, je třeba sledovat použití párových 
značek uvozujících jednotlivé celky, matematikovi je ovšem potřeba pravé a levé závorky, tedy začátku a ukončení, zřejmá. Zdůrazněme zde význam párových značek $\$$, které uvozují syntaxi matematické části textu (vzorce), o kterou se zde primárně zajímáme

Kontrola syntaxe již zapsaného se provede způsobem naznačeným v Obr 3, program př́padně upozorní na místo $\mathrm{v}$ zápise, kde přsesně je v zápise chyba. Tlačítkem $\overbrace{\mathrm{ou}}$ můžeme navíc pro názornost průběžně kontrolovat, jak bude zapisovaný vzorec ve výsledku zobrazen, viz Obr 4.

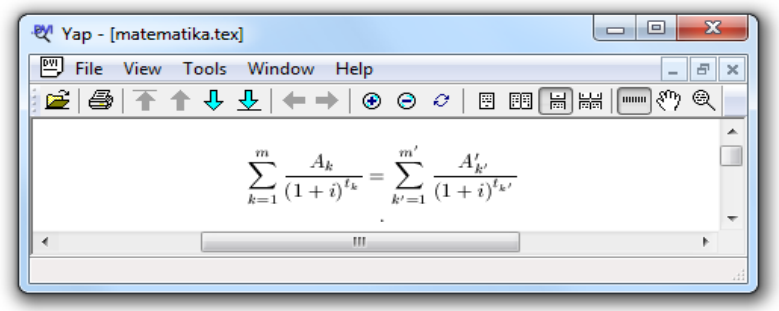

Obr 4: Kontrolni zobrazení výstupu v DVI

Mimochodem, TeX je zároveň alternativním formátem pro export, tuto vlastnost ovšem nebude třeba využít.

Pokud je vzorec v požadovaném tvaru, stačí již jen vložit text uvozený značkami $\$ \$$, tedy hledanou syntaxi tvořeného vzorce $\mathrm{v}$ jazyce TeX $\$ \$ \backslash$ large $\backslash$ sum_ $\{k=1\}^{\wedge}\{\mathrm{m}\} \backslash$ frac $\left\{\mathrm{A}_{-}\{\mathrm{k}\}\right\}\{\backslash \mathrm{le}$ $\left.\mathrm{ft}(1+\mathrm{i} \backslash \text { right })^{\wedge}\left\{\mathrm{t}_{-}\{\mathrm{k}\}\right\}\right\}=\backslash \operatorname{sum}_{-}\left\{\mathrm{k}^{\prime}=1\right\}^{\wedge}\left\{\mathrm{m}^{\prime}\right\} \backslash$ $\operatorname{frac}\left\{\mathrm{A}_{-}^{\prime}\left\{\mathrm{k}^{\prime}\right\}\right\}\left\{\backslash \operatorname{left}(1+\mathrm{i} \backslash \mathrm{right})^{\wedge}\left\{\mathrm{t}_{-}\left\{\mathrm{k}^{\prime}\right\}\right\}\right\} \$ \$$

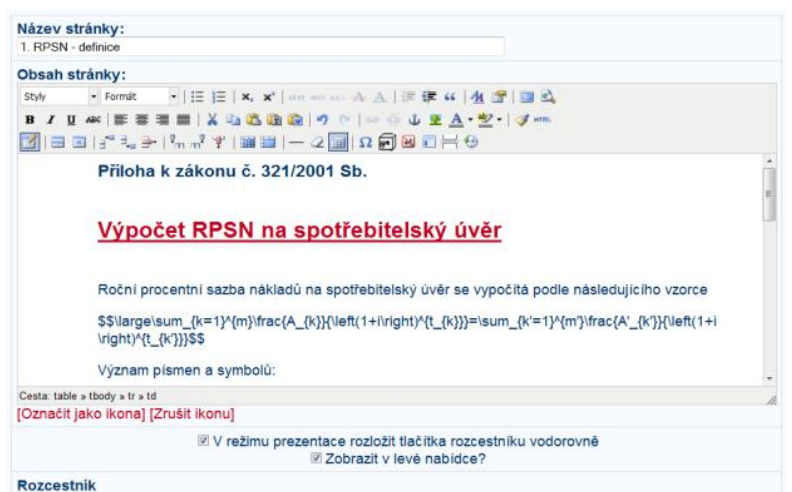

Obr 5: Editace objektu (stránky) LMS Moodle - textový formát.

na požadované místo do okna textové editace webové stránky (rozcestníku, otázky, varianty odpovědi tvořeného testu, ...), viz Obr 5.

Po osvojení si základních pravidel při psaní matematických vzorců v TeXu je obvyklé, že syntaxi pro vytvoření jednodušších vzorců je autor schopen v brzké době nahradit jejím ručním zápisem zpaměti, vrací se pouze $\mathrm{k}$ méně obvyklým znakům. Sekundárním produktem druhé metody je tedy též postupné seznamování se $s$ tvořením matematických vzorců přímo pomocí značek jazyka TeX.

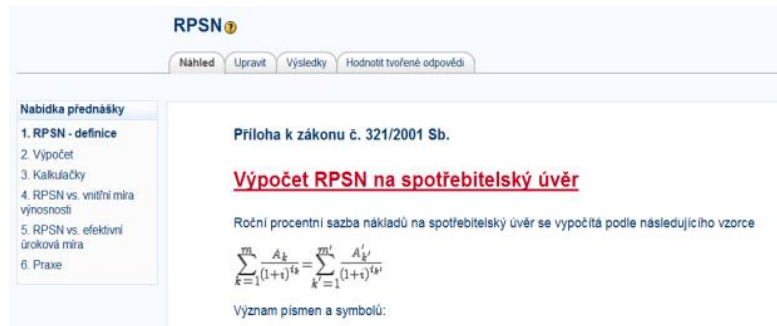

Obr 6: Náhled objektu (stránky) LMS Moodle.

Pro zastánce úprav stránek v HTML formátu zobrazme ještě ekvivalent předcházejícího zápisu v Editoru HTML v LMS Moodle. Jak je vidět v Obr 7, skutečně jde pouze o další řádek prostého odstavce uvozeného tagy $<\mathrm{p}>\mathrm{a}</ \mathrm{p}>$, který obsahuje pouze matematický text, na což odkazují již zmíněné párové značky $\$$ z jazyka TeX.

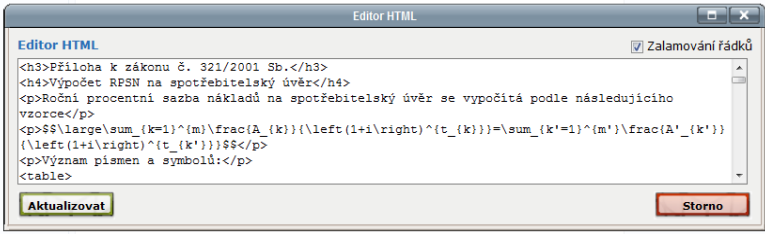

Obr 7: Editace objektu (stránky) LMS Moodle - HTML formát.

Tento způsob zápisu se obecně může použít při vkládání vzorce tvořeného $v$ jazyce $T e X$ na libovolnou webovou stránku.

\section{Výhody a nevýhody}

Nyní proved'me krátké porovnání těchto dvou nabízených metod.

V obou př́padech je možné vytvořit složitější vzorce, nalezneme zde základní symboly pro odmocniny, zlomky, matice, sumace, integrály, indexy proměnných, symboly řecké abecedy, nerovnostní znaménka..., už na tomto místě je ale nutno přiznat, že možnosti symboliky jsou u specializovaného a neustále vyvíjeného programu TeX bohatší. Vzorce jsou v obou př́ípadech na první pohled správně formátované, grafika plně postačující a esteticky vyhlížející, pro případné zvětšování obsahu stránek v LMS Moodle je ovšem u vloženého obrázku třeba najít kompromis mezi jeho bodovým rozlišením a velikostí ukládaného souboru, zatímco podoba vzorce vysázeného v TeXu je univerzální a není třeba výslednou podobu vzorce někde uchovávat. 
Dalším úhlem pohledu by mohla být dostupnost zmíněných programů. U programů firmy Microsoft můžeme hovořit o jejich velmi širokém rozšíření, přičemž jejich používání je běžnou součástí počítačové gramotnosti. Program WinEdt patří mezi shareware, je tedy také částečně volně $\mathrm{k}$ dispozici.

Jak již bylo řečeno, při porovnávání obou popsaných cest však jednoznačně hrála hlavní roli odpověd' na otázku, jak nejrychleji upravit vzorec, $v$ jehož zápisu je potřeba zpětně opravit drobnou chybu, což není nic neobvyklého. Stejně tak se nezř́dka stává, že autor potřebuje vytvořit vzorec velmi podobný tomu, který již (často pracně a zdlouhavě) vytvořil. Je nutné začít celý tento proces od úplného začátku? V jaké fázi tvoření vzorce může uživatel do provedeného procesu sázení a zobrazení vzorce znovu vstoupit a výsledný objekt tak změnit?

\section{MS Equations}

Jelikož výstupem první popsané metody je obrázek uložený někde $\mathrm{v}$ adresáři LMS Moodle, nemůže být vzorec, který zobrazuje, editován (opravován, částečně přepisován), pouze vícekrát použit, může být opakovaně uveden odkaz na stejný zdrojový soubor.

Jak tedy provést změnu $\mathrm{v}$ zobrazeném vzorci? Pokud nemáte uložený zdrojový dokument MS Word, který obsahoval výchozí objekt Editoru rovnic 3.0, musíte v tomto programu vysázet správný vzorec a zopakovat tak úplně celý výše popsaný postup, v LMS Moodle je třeba navíc odstranit z adresáře nevhodný soubor - obrázek s chybou. Ale i prri zodpovědné archivaci zdrojových objektů bude s postupem času a přibýváním vzorců stále obtížnější jejich původní zdroje $\mathrm{v}$ uložených dokumentech vyhledat, a zopakování další části postupu je potom nevyhnutelné.

Stejně tak odkazování se na zdrojový soubor bud' pomocí tlačítka př́kazem ve zdrojovém HTML kódu obecné webové stránky, může být časem a s přibývajícími obrázky stále nepřehlednějším. $\mathrm{S}$ každým $\mathrm{v}$ textu použitým vzorcem musí být na serveru uložen jeden obrázek. Jeho velikost může být $\mathrm{v}$ prŕpadě neodborného ukládání značná. Potíže pak může činit související následná potřeba konkrétních rozměrů na web vkládaného obrázku (např. width $=50 \%$ ), přičemž konstantní velikost písma je díky ručnímu vyřezávání obrázku v úvodu postupu nedosažitelná.

\section{WinEdt}

U druhé popsané metody byl výstupem zápis vysázený jazykem TeX, jehož syntaxe se objeví rovnou při editaci stránky LMS Moodle př́kazem Upravit obsah stránky. Bud' využijete textového formátu $\mathrm{k}$ názornému zobrazení a prímé editaci nebo zobrazení zdrojového kódu v HTML formátu. Opticky zápis vzorce lehce vyhledáte, je uvozen párovými značkami \$\$. Bud' jej již dovedete opravit zpaměti (viz Obr 3), případně jej kdykoli můžete překopírovat zpět do programu WinEdt, kde provedete potřebné opravy pomocí tlačítek (viz Obr 5) a poté jej nakopírovat opět na původní místo na webové stránce. Při potřebě použít tento vzorec na jiném místě dokonce postačí myší kliknout na zdrojový vzorec na zobrazené webové stránce a jeho syntaxe se objeví v nově otevřeném okně (pozor, tentokrát bez značek \$\$). Můžete jej rovnou vkopírovat na nové místo, př́padně provést jeho úpravu popsanou $\mathrm{v}$ předcházejícím odstavci.

Při tomto způsobu sázení vzorců není třeba na server ukládat žádné další soubory. Všechny vzorce jsou zobrazeny ve standardní zadané velikosti písma (např. /large ).

\section{Závěr}

Naposledy se vrat'me ke vzorci pro výpočet RPSN. Již víme, jak obtížné by bylo přejmenování parametru $K$ na $N$. Z tohoto hlediska se jednoznačně lepším nástrojem při psaní textů obsahujících matematické vzorce na webových stránkách jeví TeXovský způsob zápisu. Možnost využití programu WinEdt nebo jemu podobných $\mathrm{z}$ něj navíc činí způsob prístupný autorům bez hlubších ITC znalostí. Toto jsou důvody, proč jej při publikování na internetu autorka používá.

\section{Literatura}

[1] Moodle services [online], 2011, dostupné na: $<$ http://www.moodle.com/>.

[2] Microsoft corporartion [online], 2011, dostupné na: < http://www.microsoft.com/>.

[3] WinEdt [online], 2011, dostupné na: < http://www.winedt.com/>.

\author{
Mgr. Andrea Kubišová \\ Katedra matematiky \\ Vysoká škola polytechnická \\ Tolstého 16 \\ 58601 , Jihlava, ČR \\ Tel: +420 567141126 \\ E-mail: kubisova@vspj.cz \\ Www pracoviště: www.vspj.cz
}

